\title{
Innovation infrastructures assessment through knowledge management models
}

\author{
José Teba $^{1}$, Luis Onieva ${ }^{2}$, Gerardo Jiménez ${ }^{3}$, Jesús Muñuzuri ${ }^{4}$
}

\begin{abstract}
The design and implementation of innovative infrastructures to support business activities have been carried out in our country over the last years. There have been significant investments, which have often been unsuccessful and very expensive, since they have been based on opportunistic criteria far away from objective and professional criteria. However, there have also been successful cases that have endured over time. This paper proposes a model to help managers and authorities to make future decisions concerning the design and implementation of such infrastructures. This model should be based on a future-oriented focus and on knowledge and experience of the different stakeholders from different fields of knowledge who have an important participation in the design and development process. This model should allow assessing, a priori or at any stage thereof, the probabilities of success of such initiatives in a quantitative way.
\end{abstract}

Keywords: innovative infrastructures, knowledge management, technological parks.

\footnotetext{
${ }^{1}$ José Teba $(\bowtie)$

Dpto. Organización Industrial y Gestión de Empresas II, ETSI. CM Descubrimientos s/n, 41092 Sevilla, Spain

e-mail: teba@us.es

${ }^{2}$ Luis Onieva $(\bowtie)$

Dpto. Organización Industrial y Gestión de Empresas II, ETSI. CM Descubrimientos s/n, 41092 Sevilla, Spain

e-mail: onieva@esi.us.es

${ }^{3}$ Gerardo Jiménez $(\bowtie)$

Corporación Tecnológica de Andalucía, Isla de la Cartuja, 41092 Sevilla (Spain)

e-mail: gerardo.jimenez@corporaciontecnologica.com

${ }^{4}$ Jesús Muñuzuri $(\bowtie)$

Dpto. Organización Industrial y Gestión de Empresas II, ETSI. CM Descubrimientos s/n, 41092 Sevilla, Spain

e-mail: munuzuri@esi.us.es
} 
Resumen. En el diseño e implementación de infraestructuras innovadoras de apoyo al desarrollo empresarial que se han venido desarrollando en nuestro país, se han producido importantes inversiones que en muchos casos han sido fallidas y muy costosas, ya que se han basado, a veces, en criterios oportunistas alejados de criterios objetivos y profesionales. No obstante, sí que se han producido iniciativas de éxito que han perdurado en el tiempo. En este trabajo se propone diseñar un modelo orientado al futuro y basado en el conocimiento y experiencia profesional de los diferentes promotores y gestores profesionales que han participado en el diseño y desarrollo de este tipo de infraestructuras, provenientes de diferentes campos de conocimiento. Este modelo debería permitir evaluar a priori, o en cualquier estadio del mismo, las probabilidades de éxito de tales iniciativas de forma cuantitativa.

Palabras clave: Infraestructuras de innovación, gestión del conocimiento, parques tecnológicos.

\section{Introduction}

Most authorities and professionals agree that if companies play a key role on Innovation Systems in recent years it is because of their ability to transform $\mathrm{R} \& \mathrm{D}$ activities in economic development and wealth. That is why most governmental innovation policies focus on the participation of companies in the innovation process as a key factor in the competitiveness of different regions and countries. Of the various innovative infrastructures developed to facilitate this type of business activities, one is the Scientific and Technology Parks (STPs). STPs act as engines of innovation, as agents for economic development, and as a crucial link between companies and university researchers. They can be considered to play an important role in innovation processes and in generating the corresponding synergies.

Taking into account the above considerations, what are the key factors in the success of STPs? Is it possible to design and implement a model to help policymakers and managers in their decision-making process in order to predict the probability of success of these infrastructures in advance and avoid failed investments? Not many references in the literature focus on this specific issue for the Spanish case. Among them, Lopez (2003) analyzes the functional elements and the criteria for sizing, designing and managing STPs, which is eminently based on town planning aspects. Gonzalez (2004) studies business networks of technologybased enterprises, focusing on research cooperation, development and innovation in the field of dissemination and technology transfer in order to obtain the factors or variables that affect the performance of such networks. Ruiz (2002) presents a theoretical model based on the concept of innovation systems. Two types of models have been proposed for regional innovation systems assessment, based on two 
Chapter Number Chapter Title ("Running head - right" style)

types of analysis variables: available resources and obtained results, two factors which are closely linked (Landabaso, 1997; Landabaso et al, 1999; Morgan and Nauwealers, 1999). Following that trail, Heijs, Martinez, Baumert and Buesa (2002), presented a classification and characterization of the different Spanish regions with respect to their innovation systems.

\section{Research methodology: proposed model and results}

This paper seeks to provide a transversal model, future-oriented, to evaluate STPs and thus help in the decision-making process of public authorities and regional councils. Given that data on the future does not exist, our model is based on experience, knowledge, opinions, intuition and tacit knowledge from experts in the field of STPs belonging to different areas of knowledge (managers and researchers of scientific and technological parks, business people who have worked on or have established their businesses in these parks, as well as university professors and researchers), and who have been working and researching collaboratively in such initiatives. We based our work on the following tools: (1) the European Innovation Scoreboard, in order to determine the key indicators of success; (2) the Likert scale, used for the assessment and quantification of different parameters, aspects and criteria; (3) the EFQM quality model, used to design the structure of our model; and (4) the Delphi model, crucial in the development of this work, for collecting and identifying the tacit knowledge and professional experiences of experts in this field. We collected additional data from the Territorial Statistical Analysis System of Andalusia, and processed it using the statistical software SPSS.

\subsection{Proposed model}

In order to collect and use the knowledge, experience and intuition of experts on STPs, we directed our efforts towards the Delphi methodology against other possibilities, such as the Balanced Scoreboard, neural networks or fuzzy logic, which usually avoid or bypass the underlying intermediate processes. Table 1 shows the main details of our Delphi process, and Table 2 shows the questionnaire sent to the experts, to assess each criterion and establish the corresponding weight. The weights were set for each aspect of each criterion in a similar way. Finally, our Delphi team, in correspondence with the data gathered and the opinions expressed by the experts, proposed the criteria and aspects shown in Table 3 as the main evaluation parameters of the synthetic index. As a final result, the team proposed the model structure shown in Figure 1, where the synthetic indicator is set according to environmental, technical and strategic criteria, and their weights correspond to the results of the Delphi process. 
Table 1. Description of the Delphi experiment.

\begin{tabular}{|c|c|c|c|c|c|}
\hline Panel members & No & $\begin{array}{c}\mathbf{1}^{\text {st }} \text { round } \\
\text { responses }\end{array}$ & $\begin{array}{c}\text { \% of suc- } \\
\text { cess in the } \\
\mathbf{1}^{\text {st }} \text { round }\end{array}$ & $\begin{array}{c}\mathbf{2}^{\text {nd }} \text { round } \\
\text { responses }\end{array}$ & $\begin{array}{c}\% \text { of suc- } \\
\text { cess in the } \\
\mathbf{2}^{\text {nd }} \text { round }\end{array}$ \\
\hline $\begin{array}{c}\text { Scientific } \\
\text { experts }\end{array}$ & 35 & 29 & $83 \%$ & 20 & $57 \%$ \\
\hline Entrepreneurs & 19 & 16 & $84 \%$ & 9 & $47 \%$ \\
\hline $\begin{array}{c}\text { Administration } \\
\text { experts }\end{array}$ & 15 & 15 & $100 \%$ & 10 & $67 \%$ \\
\hline TOTAL & 69 & 60 & $87 \%$ & 39 & $57 \%$ \\
\hline
\end{tabular}

Table 2. Questionnaire sent to the participating experts.

\begin{tabular}{|c|c|}
\hline Questions & 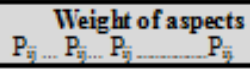 \\
\hline 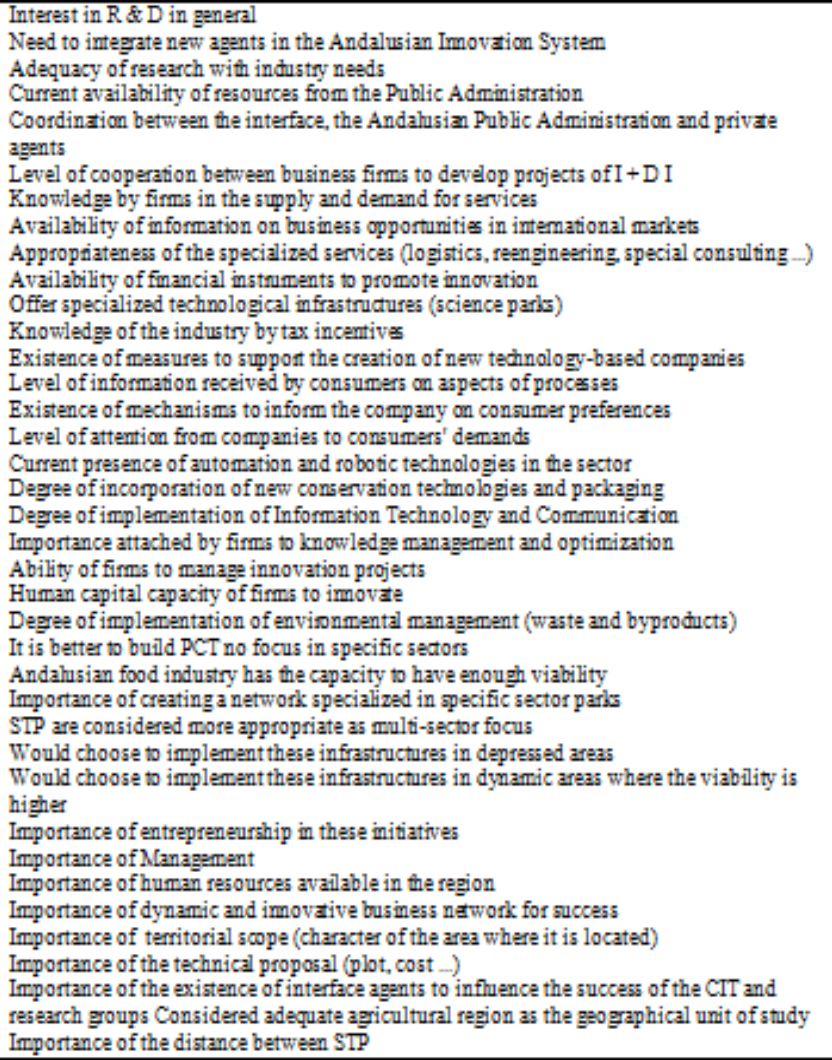 & \\
\hline$\%$ of Weight of aspects & \\
\hline
\end{tabular}


Chapter Number Chapter Title ("Running head - right" style)

Table 3. Main criteria and aspects chosen for the calculation of the synthetic index.

\begin{tabular}{|l|l|}
\hline CRITERION & ASPECT \\
\hline \multirow{5}{*}{ ENVIRONMENTAL } & SOCIOECONOMIC \\
\cline { 2 - 2 } & INNOVATON \\
\cline { 2 - 2 } & ENVIRONMENTAL ASPECT \\
\cline { 2 - 2 } & I+D+I SUPPL Y AND DENCAND \\
\cline { 2 - 2 } & SUPPORT STRUCTURES \\
\hline \multirow{5}{*}{ IECHNICAI } & LAND TRANSPORT \\
\cline { 2 - 2 } & SUPPLY \\
\cline { 2 - 2 } & SERVICES \\
\cline { 2 - 2 } & IAND AND PROPERTY LAW \\
\cline { 2 - 2 } & PLOT CHARACTERISIIC \\
\cline { 2 - 2 } & ECONONIC \\
\cline { 2 - 2 } & FINANCIAL \\
\hline \multirow{3}{*}{ STRATEGIC } & SECTOR \\
\cline { 2 - 2 } & SCIENCE AND TECHNOLOGY \\
\cline { 2 - 2 } & MODEL \\
\hline
\end{tabular}

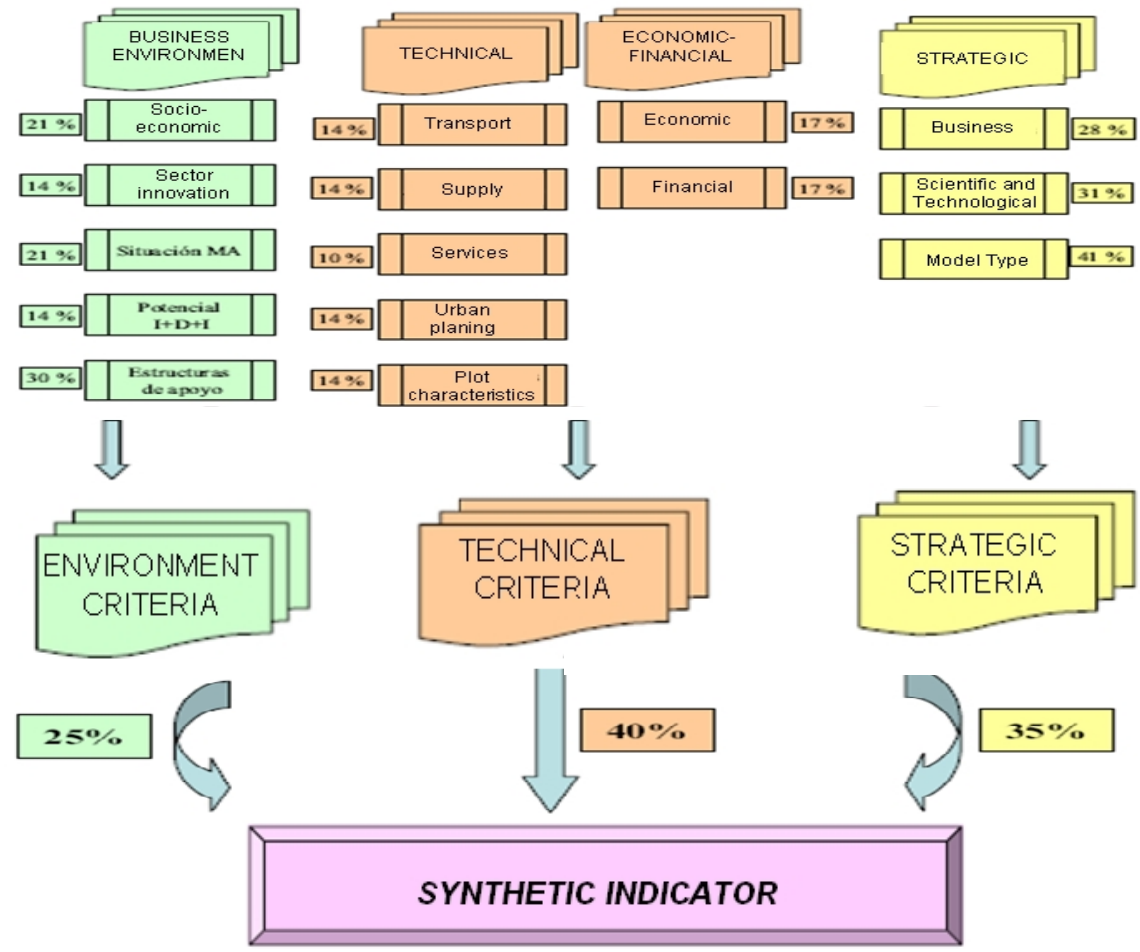

Figure 1. The proposed model 


\subsection{Application of the proposed model}

In order to validate the model, our team applied this model to a set of STPs in different development stages: (Cartuja'93 (Seville), PTA (Málaga), Geolit (Jaén), Velez-Málaga (Málaga), Agroparc (Avignon) and Bioindustry (Piemonte). The results gathered are showed in Table 4. In this table, for each STP, the first column shows the calculated Synthetic Index measured in percentage probability of success, and the remaining columns show the values obtained for the three main criteria conforming the Index and the aspects contemplated in the calculations for each criterion. The main aspect that requires improvement in each STP has been highlighted in red.

Table 4. Results after applying the model to different STPs.

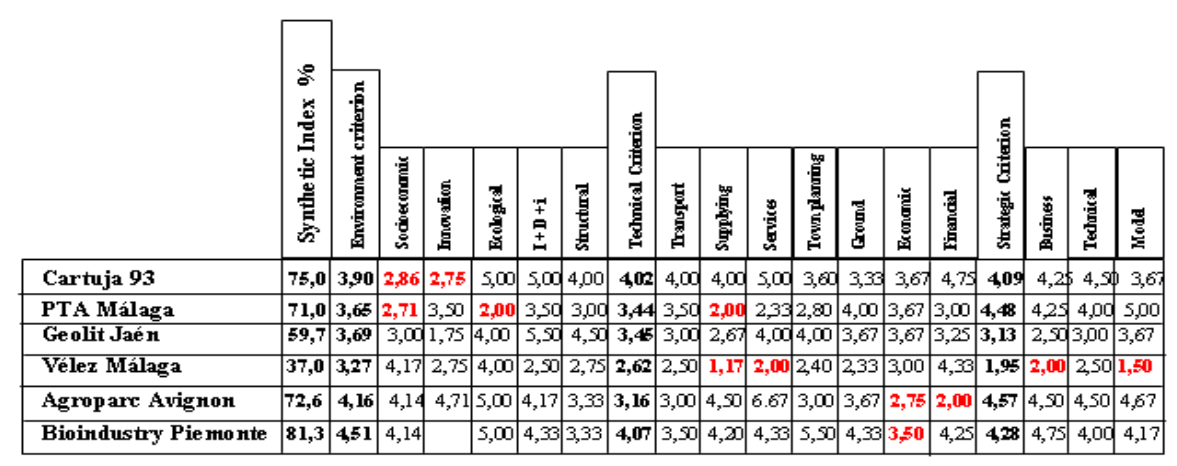

According to the results, Cartuja'93 is a clear example of success. It was built using the infrastructure from the Expo'92, with a very favorable economic and financial plan. Its economic viability is practically assured. The model shows that only small improvements can be sought in aspects that are difficult to improve because they depend on improvements of private business networks, which can only be achieved in the long term.

In the PTA case, it is a more recent initiative, based on experience and knowledge acquired in Cartuja'93. In both cases, the government support was essential, and their strengths and weaknesses are similar. Some aspects such as socioeconomic and environmental aspects should be improved, but the main difficulty lies in their complexity. However, other aspects like transport have been recently improved (road network and railway), which will hopefully further improve the future performance level. Other clear improvements can also be seen in the recent inter-university agreements (Andalucía Tech) in search of synergies in the field of innovation.

Geolit can not be considered a success case, such as its Synthetic Index shows. It is an even more recent initiative, and with a more specialized bias towards the oleic sector. The regional authorities have tried to promote $R \& D$ and value-added 
activities oriented to manufacturing processes in the industry, but this is a complex task because the international business dealers are agents with socio-political interests far beyond the regional one. Among the weaknesses we may highlight those related to socio-economic and finance, socio-economic conditions and the weakness relative to the entrepreneurial sector that needs a great improvement. It also has a nearby university, but with a lower potential and research capacity compared to the two previous cases.

Velez-Málaga can be considered a great failure without any doubt, according to its Synthetic Index. Its technical and strategic criteria are too low, possibly due to its proximity to the PTA. We believe that it would be necessary to change the model and reorient the concept in order to exploit the synergies of the proximity of this successful initiative (PTA) and its potential.

The Agroparc D'Avignon is a great success, as shown by its Synthetic index. Its main weaknesses are those concerning economic and financial aspects, but these can be considered secondary problems. It is, as its name implies, a STP focused on the agribusiness sector, and this is a key criterion in the success of the park because it is installed in a region with a clear commitment to the food industry where there is a great tradition in the $R \& D$ sector.

The Bioindustry Park is without any doubt the greatest success among the analyzed STPs. The results obtained after applying the model to it present a very high score for the synthetic index and the rest of criteria and aspects. This STP does not really need any specific improvement, since the lowest values, basically related to economic and financial aspects, are significantly high.

\section{Conclusions}

We have developed a transversal model for the evaluation of the success of STPs, following a Delphi process involving a relevant number of experts in the field. Innovation processes represent a rupture with the past trend, in the way of seeing and / or perform the different processes, activities, etc. Therefore, the use of historical data to validate models concerning future expectations should be avoided when possible, and use instead the previously mentioned "future data" based on the knowledge, experience and intuitions of the different knowledge stakeholders mentioned above, for the validation of such models.

According to our Delphi team, other professionals involved in the project, and other users who have used the model (Technological Corporation of Andalusia, regional and national authorities), the results of the evaluation provided by model, as applied to the different parks analyzed, present a fair and sound assessment. They all agree in considering it a valuable tool to analyze the possible future implementation of a STP or to assess the current status of existing STPs. 
Another interesting aspect highlighted by its users is the ease of use and understanding, and the reliability shown by the model. Users believe that having access to information of the intermediate levels of the model allows them to interpret this information in order to suggest improvements or carry out simulation processes which would result from the modification of the input data.

In this model, tacit knowledge and experiences and personal views of expert professionals are embedded in its structure and relative weights, which were obtained according to the different criteria and aspects proposed by the experts. This limits the possible sensitivity analysis, since this structure and weights should not be modified because the essence of the knowledge of the expert group would be lost. A correct application of a sensitivity analysis should be limited to possible changes in some of the input data (e.g. what would be the result if a particular initiative improves technological infrastructure (cable network) or access infrastructure?), without affecting the model structure.

Others analytical and more conventional approaches used in the past, based on economic and financial viability, represent in our opinion a narrower framework. Our model tries to take into account all the relevant factors, incorporating criteria and aspects concerning the environment, technical and strategic issues, that we consider are more complete and demanding from the perspective of the expert group knowledge that permeates the model structure.

\section{References}

1. González B. (2004) Análisis de las redes de cooperación en innovación y tecnología entre empresas de los Parques Tecnológicos. Universidad de Vigo.

2. HeijsJ.J., Martinez, M., Baumert, T. y Buesa, M. (2002) Los sistemas regionales de innovación en España: una tipología basada en indicadores económicos e institucionales. Economía Industrial, 347, 15-32.

3. Landabaso, M. (1997) The promotion of innovation in regional policy. Entrepreneurship \& Regional Development.

4. Landabaso, M., Oughton, C. y Morgan, K. (1999) Learning regions in Europe: Theory, Policy and Practice through the RIS. International Conference on Technology and Innovation Policy, Austin USA.

5. López, C. (2003) Un nuevo equipamiento territorial: Los Parques Científicos y Tecnológicos. Análisis de la experiencia española. Universidad Politécnica de Madrid.

6. Morgan, K. y Nauwealers, C. (1999) Regional Innovation Strategies. London, The Stationery Office.

7. Ruiz, F. (2002) Las actividades de investigación científica y desarrollo tecnológico en el subsistema empresarial de innovación andaluz: el espacio relacional de las empresas de $\mathrm{I}+\mathrm{D}$. Universidad de Sevilla. 